\title{
An empirical study of customer usage and satisfaction with e-banking services in the Republic of Macedonia
}

\author{
Meri Boshkoska \\ Faculty of Economics - Prilep, "St. Kliment Ohridski" University - Bitola, Republic \\ of Macedonia \\ meribb@yahoo.com \\ Kosta Sotiroski \\ Faculty of Economics - Prilep, "St. Kliment Ohridski" University - Bitola, Republic \\ of Macedonia \\ kostasotiroski@gmail.com
}

\begin{abstract}
Recent developments in the field of information and communication technologies (ICTs) have created new opportunities for enhancing both the operations and competitiveness within the banking sector. The application of contemporary ICTbased solutions has resulted in significant changes in the traditional banking business, through the involvement of brand new approaches in the process of distribution of banking products and services to customers. As a part of the services offered by any modern bank, e-banking has become a synonym for an efficient system aimed at delivering traditional banking services through electronic communications channels, available to anybody, anywhere and anytime. The goal of the paper is to perform an empirical analysis of the current situation regarding the level of customer usage and satisfaction with e-banking services in the Republic of Macedonia. The study will enable us to determine which variables affect the level of adoption and satisfaction with e-banking services. The study is fully based on the statistical data analysis of the responses gathered from a representative sample of e-banking customers.
\end{abstract}

Keywords: customer loyalty, customer satisfaction, e-banking, m-banking, statistical analysis.

JEL classification: C1, G21.

DOI: 10.2478/crebss-2018-0001

Received: February 10, 2018

Accepted: June 11, 2018

\section{Introduction}

The rapid development and application of information and communication technologies (ICTs), especially the vast proliferation of Internet and Web 2.0 paradigm in the recent years, have profoundly transformed the traditional ways of doing business in the banking sector. Bank institutions have significantly enriched their 
offerings with brand new products and services, being highly customized to meet the needs of their customers. In this context, Hadžić (2015) shares the findings of other authors, pointing out the fact that banking institutions, which have succeeded in adjusting themselves to the needs of their customers in a prompt and an adequate way, are the most successful ones. They have to focus their attention on the changes that continually occur in the contemporary business surrounding as well as to introduce new and innovative processes, products, and services on a regular basis, in order to manage those changes on time and in an effective manner (Zagorac, 2014). Similarly, Rončević (2006), while making a comparison between the traditional and the contemporary banking, has stated out that the later one is being characterized by dynamic development and application of new strategies, oriented strictly towards the clients. This behaviour is entirely opposite to the philosophy of the traditional banking, where bank institutions have been oriented mainly towards themselves. In fact, the rise of electronic banking (e-banking) is a direct consequence of the ICTs utilizations, which have intensely altered the ways of communication and distribution of banking services towards clients. According to Alam, Musa and Hasan (2009), traditional bank institutions seek to lower their operating costs, improve the delivery of banking services for customers, and retain customers on a long run by offering Internet banking services.

This study focuses on the assessment of electronic banking services' adoption and the valuation of satisfaction with individual customers in the Republic of Macedonia. By examining the current situation in the country concerning the perceived levels of customer usage and satisfaction with e-banking services, the paper aims to determine which variables affect the usage of e-banking services at most as well as whether there is a mutual relationship between the perceived levels of satisfaction vis-ò-vise-banking services and customers' loyalty.

The research methodology consists of combination of different methodology aspects that are based on:

- content analysis of various research papers that are dealing with e-banking issue;

- empirical research fulfilled by questionnaire that would cover 409 examinees from the towns in Republic of Macedonia selected by random sampling plan;

- descriptive statistics from the aspect of structure analysis and suitable graphical presentation of data;

- implementation of suitable statistical conclusion making or precisely, testing of set hypothesis, which would be completed with suitable software backup and using the contingency test $\left(\chi^{2}\right)$.

As a result from our research, there are recommendations for banks on the way how to increase conscience and usage at their clients for usefulness from using mobile banking in the part Conclusion and Recommendations.

Our research and results make a significant contribution to the existing literature on electronic banking in the country, since there are no many empirical studies that examine this substance in a profound and consistent manner. As such, this research will enrich the existing literature in the field of e-banking in the Republic of Macedonia. To the best of our knowledge, only Bucevska (2012) have carried out a similar research on the factors affecting the adoption of electronic banking services in a single Macedonian bank - "Komercijalna Banka" AD Skopje. Their results indicated that adoption and usage of e-banking services depend mostly of customers' age and their level of education. On the other hand, our study is based on a more profound research that takes into account all 14 banking institutions that currently exist in the Republic of Macedonia. Besides the theoretical contribution, our 
study will significantly enrich the knowledge of banking managers and information system developers, to understand what kind of changes should be made in order to increase the customers' adoption and satisfaction level of e-banking services in the future.

The rest of the research is structured as follows. The literature review is presented in the second section, which focuses on: the understanding of the results of the implementation of information and communication technology in the banking sector; the meaning of e-banking services; the factors affecting the level of ebanking adoption, as well as the consumer satisfaction and loyalty in developing countries. Section three presents the research design, the methodology applied and the working hypothesis. The results of the data analysis are presented within the fourth section of the paper, alongside a discussion about the empirical findings. Last section of the paper presents the conclusion and recommendation of the study.

\section{Literature Review}

Many researchers and practitioners point out the services' quality as an essential tool that differentiates companies from their competition (Karim, Chowdhury, 2014). The quality of services is a result of the comparison between the clients' expectations and their perceptions (Gronroos, 1984). Delivering a quality service means adjusting to customers' expectations on a permanent basis (Parasurman, Zeithaml, Berry, 1985).

Globalization, deregulation and financial innovations have all a significant impact on increasing the competitive levels in the banking sector. Therefore, banking institutions have to pay a great attention to the improvement of the quality of their services, which is a key premise to their better positioning on the market (Radojević, Marjanović, 2011). The quality of banking services along with the clients' satisfaction and loyalty are both significant determinants that underlay the success in modern banking (Islam, Ali, 2011).

Nowadays, legal banking institutions are facing an increasing competition caused by non-banking firms that offer a diversity of financial services. The concurrency is manifested in the domain of price formation, but also regarding the types and quality of financial products and services. In such adverse business environment, banking institutions have coped with the challenge of finding out novel distribution and communication channels to their clients as well as developing new and innovative products and services (Poposka, 2008).

Since the banking sector is a service-oriented business, the appliance of contemporary technologies is necessary to improve the quality of services (Karim, Chowdhury, 2014). Actually, the development and application of the state-of-the-art information and communication technologies (ICTS) have enabled the banking institutions to create sophisticated products and to raise the quality of their services on a much higher level. Rončević (2006) points out that the application of such new technologies results in many benefits for banking institutions, including the following ones: reduction of costs, increasing the market share, better communication with the clients as well as development of new products and services.

One of the most evident results that arise from the direct appliance of the ICTs in banking sector is the development and proliferation of e-banking. There is a plethora of definitions about what actually means the term 'e-banking'. To name a few, Srivastava (2007) defines e-banking as a system which allows the customers to access their banking accounts and get information about banking products and services over the Internet. According to Drigă and Isac (2014), e-banking means automatic submission of both traditional and new banking products to clients via 
electronic ways. Fullenkamp and Nsouli (2004) define e-banking as a usage of methods for delivering the traditional banking services, using any payment media.

E-banking is a service that can be accomplished using specific communication instruments, according to which it can be divided into phone banking, mobile banking, home banking, Internet banking and mail banking (Chovanova, 2006). Alternatively, according to Drigăandlsac (2014), e-banking includes the following types of services: home banking, PC banking, mobile banking and Internet banking. Kovačević and Đurović (2014) point to the need to distinguish between the terms 'online banking' and 'Internet banking'. Namely, the case when the clients connect to their bank directly, using dedicated software in order to carry out their banking transactions, is called 'online banking'. On the other hand, the advantage of Internet banking is that there is no need for installing and using dedicated banking software i.e. all that the customer needs is an Internet access. Thus, the client can perform the banking transactions from anywhere and anytime, as opposed with online banking, where customers can access their bank accounts only by using their personal computers with preinstalled software. It is also worthy to mention that with Internet banking, the transactions data are not kept on the users' personal computers, but instead on servers in the banks, which implies a significantly higher levels of protection and safety vis-à-vis the potential misuse of customers data.

Several years ago, the clients have to go into the banking branches or city branches in order to perform any financial transactions i.e. to satisfy their needs. Nowadays, the situation has changed dramatically. The number of clients, both persons and companies that have adopted e-banking as an ultimate way of managing their financial obligations is growing continually.

Poposka (2008) elaborates that Macedonian banks offer the following e-banking products and services: conventional e-services, electronic products (debit/credit cards, e-trading), and contemporary electronic services (Internet banking and online investing).

The analysis of current academic research shows that different factors affect the adoption of e-banking in different countries, depending on their economic, social, and cultural development. Specifically, many researchers emphasize that the customers' perceived level of usefulness, simplicity, effectiveness and speed of performing e-banking operations are the most often mentioned factors that affect the usage rate of e-banking services (Delafrooz et al., 2013). Alternatively, Montazemi and Saremi (2013) argue that the trust itself is the primary factor that affects clients' decision to use the Internet banking. According to Suki (2010), among the most prominent primary factors are the perceived perception, complexity, and hedonic-oriented features of banks' Internet webpages. In addition, the results of a study conducted by Kumbhar (2011) vis-à-vis the most important factors affecting customers' satisfaction in e-banking are as follows: brand perception, perceived value, cost effectiveness, easiness of usage, and convenience. Moreover, Australian banks that provide user-friendly interface, website reliability, transactional capabilities, and activities that foster customers' education about online risks are more successful in the area of e-banking (Poder, 2005).

Previous research conducted in the area of e-banking may help in structuring the recommendations about what exactly Macedonian banking institutions have to undertake in order to increase the application of e-banking services and their customers' satisfaction regarding e-banking services they offer. The implementation of such recommendations in practice will allow banking institutions to gain their trust with their clients on a long run, but also it will let them strengthen or improve their concurrent position in the contemporary business surrounding. Mia, Rahman and 
Debnath (2007) give recommendations about what the banking institutions can do in order to increase the usage of e-banking services.

Banking institutions have to develop novel marketing strategies to inform their clients about the benefits of using e-banking services as well as to offer training for certain categories of clients. Such marketing strategies should be focused on increasing clients' awareness about the positive effects of using e-banking services, which will stimulate the demand for their electronic services (Muslime, Ramadhan, 2011). In addition, they have to enhance their existing products and services continually, besides the inclusion of a brand new creative, yet innovative products and services.

Among the others, the user-friendly interface, the website design, and the safety of financial transactions are considered the most prominent factors that have a great influence on the usage of e-banking services and the customers' satisfaction.

The customer loyalty towards any production- or service-oriented company depends on most of the quality of products and/or services they use. Oliver has described the notion of loyalty as "a deeply held commitment to rebuy a preferred product/service consistently in the future" (Dickinson, 2014). In the same way, the loyalty of banking clients depends proportionally on their satisfaction vis-à-vis the quality of the banking services delivered by their banking institutions. One of the key goals that is always explicitly pointed out by banking management teams is their strong commitment towards gaining their clients' loyalty on a long run. Banking managers are aware of the fact that their clients are quite well informed, and consequently, their expectations and needs are always more articulated, which, in fact, impose the need of continuous introduction of new products and services, and a continuous enhancement of the existing ones. In this context, it is known that the success of one of the most famous banks in the Republic of Macedonia, "Stopanska Banka" AD Skopje, is a direct consequence of their informing about their clients' needs and demands on time, and the prompt creation of their products and services in a segmented manner (Petrovski, 2012).

The implementation of e-banking services can gain exceptionally positive implications for both the banking institutions and their clients. Namely, it is a great opportunity for them to standardize the delivery of their services to customers, as well as to increase their profitability by reducing the services' processing costs. At the same time, it significantly increases the chances of attracting more clients. From the clients' perspective, the usage of e-banking services can considerably spend their money and reduce their expenses, since it allows them not only to access the financial services very easily, but also to manage their own finance assets on a credible and efficient manner, without any spatial and temporal limitations (AlSmadi, 2012).

\section{Research designs and methodology}

This part will provide the conceptual model for our study based on the literature review. Since the main objective of our paper is to identify and to determine which variables affect the level of adoption and satisfaction of e-banking service, the research concept of this study is shown in Figure 1. 


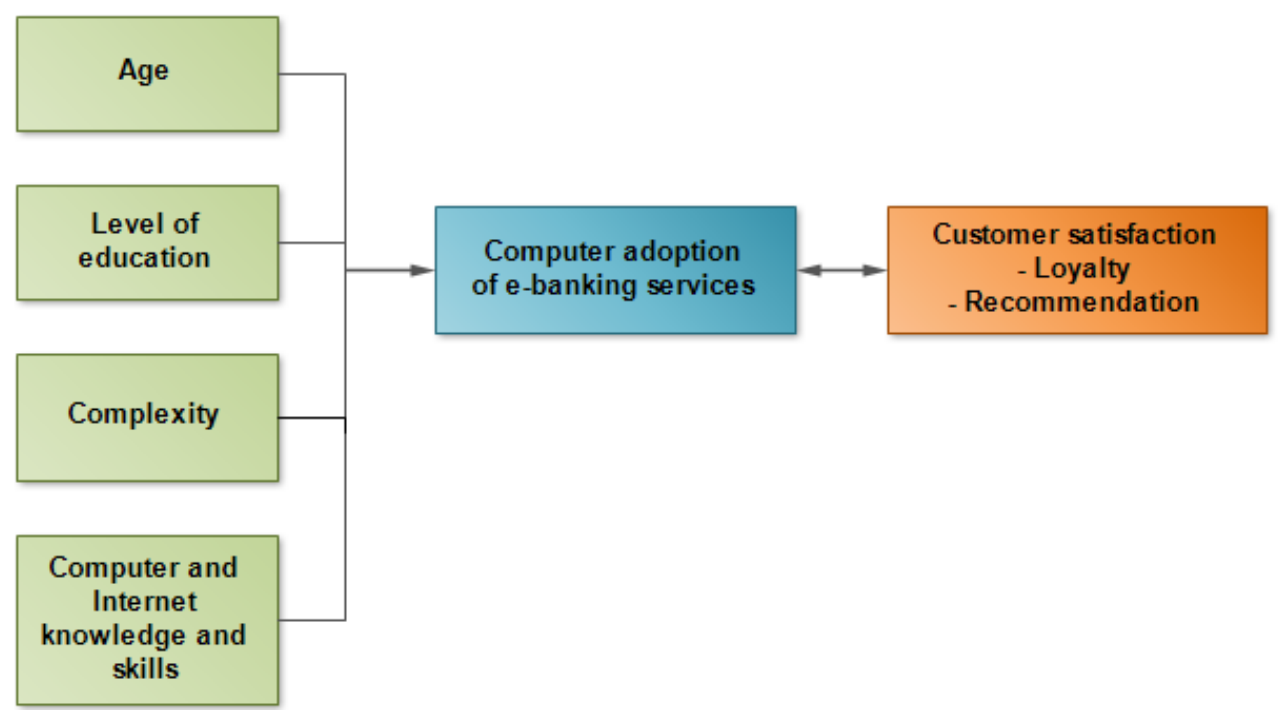

Source: Authors' creation.

Figure 1 The research concept of the study

On the basis of our model, the research attempts to answer the following questions:

- Which factors affect the adoption of e-banking services in the Republic of Macedonia?

- What is the level of customer adoption and satisfaction with e-banking in Macedonian banking sector?

- Whether the high level of quality of e-banking services influence on customer

- Loyalty and their bank selection?

In order to accomplish successfully the defined research objective, the following plan of statistical research has been implemented: Identification of the primary sources of statistics about the usage of e-banking services in the Republic of Macedonia; Defining of the basic hypothesis as well as defining of the performed individual hypotheses; Generating questions in the Survey; Designing plans of the sample and selection of appropriate sample class that will meet the requirements of objectivity, coincidence, representativeness and documentation support; Distribution of the Survey electronically through the Internet, and face to face interviewing of the predetermined sample; Design and development of a database of Surveys and processing of statistical data with the Statistical Package for the Social Sciences (SPSS); Obtaining information from statistical analysis and statistical conclusion on the data from the survey, based on which the relevant factors that affect the use of E banking services in the Republic of Macedonia are identified.

The research instrument used in the study is an interview questionnaire, which contains 24 questions classified into three sections as:

I. General Information;

II. Data on Usage of Electronic Banking Services; and

III. The Level of Satisfaction and Loyalty of Bank Customers.

The data was obtained by sending the interview questions through an email and through face-to-face interview of 409 individual clients of all Macedonian commercial banks chosen by random sampling plan. The survey was conducted in the period from February to April 2016.

The first seven questions in the questionnaire refer to general characteristics of examinees (gender and age structure, place of residence, level of education, employment status, monthly income of household and level of computer knowledge 
and skills). The second group of questions (9) requires data on the bank choice, internet access to bank account, familiarity with e-banking and mobile banking, modalities and frequency in using electronic bank services as well as reasons for using those i.e. not using electronic services and significance of those bank services. The third group of questions is conceptualized to obtain data on satisfaction and loyalty of bank clients and based on those 8 questions are defined and they refer to using and problems with ATM machines, banks' web pages, mobile and e-banking as well as satisfaction and loyalty to banks from the aspect of realized electronic bank services.

Collected data from the on-line survey realized via internet are gathered in statistical data base in the Statistical Package for the Social Sciences (SPSS). Suitable statistical methods and techniques are used for processing data from that data base. Namely, descriptive statistics from the aspect of structure analysis and suitable tabular presentation of the data is used. Also, in the survey research suitable and significant estimation of the results' safety is defined i.e. a risk of $5 \%$ or safety rate of $95 \%$ in statistical conclusion. That implies implementation of suitable statistical conclusion or precisely, testing of set hypothesis, which would be implemented with suitable software support and using test of contingency $\left(\chi^{2}\right)$.

Based on objective, research questions and the conceptual model the research hypothesis of the study are:

- $\mathbf{H}_{1}$ : There is a significant relationship between the use of e-banking services and the level of customer satisfaction of their banks.

- Ho: Customer satisfaction does not depend on quality and offer of e-banking services.

- $\mathrm{H}_{\mathrm{A}}$ : Customer satisfaction depends on quality and offer of e-banking services.

On the basis of the previously defined basic hypothesis, the following specific hypotheses can be defined:

- $\mathbf{H}_{2}$ : Computer knowledge and skills affect the level of using banking services in the Macedonian banking sector.

- $\mathbf{H}_{3}$ : The level of consumer satisfaction with e-banking does not depends on the criteria for bank selection.

- $\mathbf{H}_{4}$ : The level of consumer satisfaction with e-banking services does not depend on the reasons for using various e-banking services.

- $\mathbf{H}_{5}$ : The dissatisfaction with the e-banking services does not depends of the nonusing of various E banking services.

\section{Results and findings}

Table 1 describes the demographic profile of the participants, which consists of gender, age, level of education, income level, working status and computer and Internet knowledge and skills.

Data show that of 409 interviewers, $71.4 \%$ have access to their checking account via internet and $28.6 \%$ do not have an electronic access. Electronic access to checking account of clients depends on age structure, level of acquired education, total monthly income in the family and level of computer knowledge and skills. Replies to the questions: "Are you familiar with m-banking?" and "Are you familiar with e-banking?" are the key for identifying the level of clients' being informed on possibility for using e-banking services from their banks. If we make a comparison between the data of the previous two questions, we can come to a conclusion that $27.1 \%$ of the examinees know about, but are unable to use mobile banking; and $33.5 \%$ are not familiar with the mobile banking as a service that Macedonian banks 
offer. These percents are smaller with the other question i.e. 14.9\% of examinees replied that they know about electronic banking services, but they cannot use them; $9.3 \%$ replied that they are not familiar with this kind of bank service.

Table 1 Structure of respondents according to different variables

\begin{tabular}{|l|l|c|}
\hline Demographic variable & Demographic characteristic & Structure (in \%) \\
\hline \multirow{5}{*}{ Gender } & Male & 44.50 \\
& Female & 55.50 \\
\hline & $18-24$ years & 13.20 \\
& $25-30$ years & 22.25 \\
& $31-40$ years & 34.47 \\
& $41-50$ years & 19.32 \\
& $51-60$ years and above & 3.91 \\
\hline \multirow{5}{*}{ Level of education } & Primary education & 0.24 \\
& High school & 21.76 \\
& Higher education & 3.67 \\
& University degree & 50.61 \\
& Master degree & 14.67 \\
Income level & Ph.D. in Science & 9.05 \\
\hline \multirow{5}{*}{ Working status } & Up to 10.000 denars & 7.27 \\
& 10.000 - 20.000 denars & 11.78 \\
& 20.000 - 30.000 denars & 24.31 \\
& 30.000 - 50.000 denars & 30.58 \\
& Above 50.000 denars & 26.07 \\
\hline \multirow{5}{*}{ Computer and Internet } & State company & 39.12 \\
knowledge and skills & Private company & 10.51 \\
& Unemployed & 8.07 \\
& Unemployed students & 3.67 \\
& Retirees & 3.67 \\
\hline & None & 2.23 \\
& Average level & 3.71 \\
& Advanced level & 49.75 \\
& An expert & 35.89 \\
\hline
\end{tabular}

Note: 1 euro $=61.7$ denars

Source: Adopted from Lichtenstein and Williamson (2006).

A total of 329 examinees who use electronic banking, $62.3 \%$ replied that the use of electronic banking has a great importance for their banking services and only $13.1 \%$ think that using electronic banking is not significant.

The percentage of users who are prepared to regularly make payment via internet is not on a satisfactory level and it is $11.5 \%$. $25.9 \%$ from the examinees or every fourth examinee make a review on their checking account status via info terminals; $34.5 \%$ of examinees are informed on their account status via SMS message; and, their $42.8 \%$ of examinees receive monthly reports for the status of their credit card via e-mail.

Out of 292 examinees who use e-banking services, $88.4 \%$ are satisfied with electronic banking services, $8.2 \%$ do not know and only $3.4 \%$ are not satisfied with electronic banking services offered by the bank. $82.5 \%$ of the examinees who use ebanking services would recommend their bank due to satisfaction from offered electronic banking services; $14.4 \%$ do not know; and only $3.1 \%$ of the examinees who use electronic banking services would not recommend it. Also, $87 \%$ of examinees, users of electronic banking services, do not think of changing the bank due to 
dissatisfaction with electronic banking services offered by the bank; $11 \%$ do not know; and only $2.1 \%$ of examinees, users of electronic banking services, are dissatisfied from the offer of e-banking services and seriously reconsider changing the bank. These analyses may lead to a conclusion that most of the examinees are mainly satisfied by electronic services of their banks as well as the fact that using or not using of these services does not affect their decision for choosing a bank they will cooperate with.

\section{Hypothesis testing}

In order to accomplish the research goal and answer the research questions several hypothesis were tested in this study. We used a statistical software program (Statistical Package for Social Science (SPSS)) to test a set of hypothesis, which would be completed with suitable software backup and using the contingency test $\left(\chi^{2}\right)$. Along we provide some of the results of the tested hypothesis.

\section{Hypothesis referring to the frequent use of various modalities of banking services and the level of computer knowledge and skills.}

Basic Hypothesis: Frequent use of the various modalities of banking services does not depends on the level of computer knowledge and skills of the respondents.

Table 2 Results of tested hypothesis referring to the frequent use of various modalities of banking services and the level of computer knowledge and skills

\begin{tabular}{|l|r|r|r|r|l|}
\hline Hypothesis & $\begin{array}{c}\text { Statistics } \\
\text { (calculated value) } \\
\text { of Chi-Square Tests }\end{array}$ & $d f$ & $\begin{array}{c}\text { Theoretical (table) } \\
\text { value of the Chi- } \\
\text { Square }\end{array}$ & $\begin{array}{c}\text { Asymp. Sig. } \\
\text { (2-sided) }\end{array}$ & $\begin{array}{c}\text { Statistical conclusion } \\
\text { (acceptance or } \\
\text { rejection of the } \\
\text { hypothesis) }\end{array}$ \\
\hline Hypothesis 1 & 18.604 & 16 & 26.2962 & 0.290 & Accepted \\
Hypothesis 2 & 32.275 & 20 & 31.4104 & 0.040 & Not accepted \\
Hypothesis 3 & 12.311 & 16 & 26.2962 & 0.722 & Accepted \\
Hypothesis 4 & 35.505 & 20 & 31.4104 & 0.030 & Not accepted \\
Hypothesis 5 & 41.936 & 16 & 26.2962 & 0.000 & Not accepted \\
Hypothesis 6 & 57.370 & 20 & 31.4104 & 0.000 & Not accepted \\
Hypothesis 7 & 56.866 & 20 & 31.4104 & 0.000 & Not accepted \\
Hypothesis 8 & 23.111 & 20 & 31.4104 & 0.283 & Accepted \\
\hline
\end{tabular}

Source: Authors' creation.

From the data given in the table 2 following statistical conclusion can be drawn:

- The frequent use of the notification for the current account balance by SMS, info terminals, and counter services does not depends on the respondents' level of acquired education.

- The frequent use of the: m-banking, monthly statements for the credit card by email, ATM, electronic payment via Internet and status check of debit/credit cards over the Internet does depends from the respondents' level of acquired education.

Hypothesis referring to the level of consumer satisfaction with e-banking services and criteria for bank selection.

Basic Hypothesis: The level of consumer satisfaction with e-banking does not depends on the criteria for bank selection. 
Table 3 Results from tested hypothesis referring to the level of consumer satisfaction with e-banking services and criteria for bank selection

\begin{tabular}{|l|r|r|r|r|l|}
\hline Hypothesis & $\begin{array}{c}\text { Statistics } \\
\text { (calculated } \\
\text { value) of Chi- } \\
\text { Square Tests }\end{array}$ & df & $\begin{array}{c}\text { Theoretical } \\
\text { (table) value of } \\
\text { the Chi-Square }\end{array}$ & $\begin{array}{c}\text { Statistical } \\
\text { Asymp. Sig. } \\
\text { (2-sided) }\end{array}$ & $\begin{array}{c}\text { conclusion } \\
\text { (acceptance or } \\
\text { rejection of the } \\
\text { hypothesis) }\end{array}$ \\
\hline Hypothesis 1 & 4.934 & 2 & 5.99147 & 0.085 & Accepted \\
Hypothesis 2 & 7.796 & 2 & 5.99147 & 0.020 & Not accepted \\
Hypothesis 3 & 0.525 & 2 & 5.99147 & 0.769 & Accepted \\
Hypothesis 4 & 1.166 & 2 & 5.99147 & 0.558 & Accepted \\
Hypothesis 5 & 0.072 & 2 & 5.99147 & 0.964 & Accepted \\
\hline
\end{tabular}

Source: Authors' creation.

From the data given in the table 3 following statistical conclusion can be drawn:

- The level of the client satisfaction with e-banking services does not depend on the: banking services and products quality, confidence, safety and on the employees' attitude.

- The level of the client satisfaction with e-banking services does depend on the offer of the banking services (e-banking, m-banking ATMs, info terminals ...). The satisfaction from e-banking services depends on the offer of electronic services by the bank (e-banking, mobile banking, ATMs, into-terminals ...).

\section{Hypothesis referring to the level of satisfaction and reasons for using various e- banking services.}

Basic Hypothesis: The level of consumer satisfaction with e-banking services does not depend on the reasons for using various e-banking services.

Table 4 Results from tested hypothesis referring to the level of satisfaction with ebanking services and reasons for using various e-banking services

\begin{tabular}{|c|r|r|r|r|r|}
\hline Hypothesis & $\begin{array}{c}\text { Statistics } \\
\text { (calculated } \\
\text { value) of Chi- } \\
\text { Square Tests }\end{array}$ & df & $\begin{array}{c}\text { Theoretical } \\
\text { table) value of } \\
\text { the Chi-Square }\end{array}$ & $\begin{array}{c}\text { Asymp. Sig. } \\
\text { (2-sided) }\end{array}$ & $\begin{array}{c}\text { Statistical } \\
\text { conclusion } \\
\text { (acceptance or } \\
\text { rejection of the } \\
\text { hypothesis) }\end{array}$ \\
\hline Hypothesis 1 & 7.098 & 2 & 5.99147 & 0.028 & Not accepted \\
Hypothesis 2 & 9.193 & 2 & 5.99147 & 0.010 & Not accepted \\
Hypothesis 3 & 5.851 & 2 & 5.99147 & 0.054 & Accepted \\
Hypothesis 4 & 2.651 & 2 & 5.99147 & 0.266 & Accepted \\
Hypothesis 5 & 0.360 & 2 & 5.99147 & 0.835 & Accepted \\
\hline
\end{tabular}

Source: Authors' creation.

From the data given in the Table 4 following statistical conclusion can be drawn:

- The level of satisfaction with e-banking services does not depend on the: saving time and money, controlling, monitoring and 24/7 access to the banking account as well as on the safety standards and confidentiality in the usage of various e-banking services.

- The level of satisfaction with e-banking services does depend on the: quick and simple usage and performing of the banking transaction from any location.

\section{Hypothesis referring to the dissatisfaction with the e-banking services and the reasons for not using various e-banking services.}

Basic Hypothesis: The dissatisfaction with the e-banking services does not depend of the non-using of various $E$ banking services. 
Table 5 Results from tested hypotheses that refer to the dissatisfaction with the ebanking services and the reasons for not using various e-banking services

\begin{tabular}{|l|r|r|r|r|l|}
\hline Hypothesis & $\begin{array}{c}\text { Statistics } \\
\text { (calculated } \\
\text { value) of Chi- } \\
\text { Square Tests }\end{array}$ & df & $\begin{array}{c}\text { Theoretical } \\
\text { (table) value of } \\
\text { the Chi-Square }\end{array}$ & $\begin{array}{c}\text { Statistical } \\
\text { Asymp. Sig. } \\
\text { (2-sided) }\end{array}$ & \multicolumn{1}{c|}{$\begin{array}{c}\text { conclusion } \\
\text { (acceptance or } \\
\text { rejection of the } \\
\text { hypothesis) }\end{array}$} \\
\hline Hypothesis 1 & 7.304 & 2 & 5.99147 & 0.026 & Not accepted \\
Hypothesis 2 & 1.879 & 2 & 5.99147 & 0.391 & Accepted \\
Hypothesis 3 & 16.502 & 2 & 5.99147 & 0.000 & Not accepted \\
Hypothesis 4 & 0.423 & 2 & 5.99147 & 0.809 & Accepted \\
Hypothesis 5 & 2.971 & 2 & 5.99147 & 0.226 & Accepted \\
Hypothesis 6 & 0.875 & 2 & 5.99147 & 0.646 & Accepted \\
Hypothesis 7 & 2.919 & 2 & 5.99147 & 0.232 & Accepted \\
Hypothesis 8 & 0.423 & 2 & 5.99147 & 0.809 & Accepted \\
\hline
\end{tabular}

Source: Authors' creation.

From the data given in the Table 5 following statistical conclusion can be drawn:

- The dissatisfaction with the e-banking services does not depend on the: notuser-friendly electronic banking software, feeling that the conversation with the banking officer is safer, fact that user account can be targeted by hackers, lack of sufficient clarity and/or control of the bank account and transactions, lack of knowledge of respondents on how to use a e-banking services and respondents' habit.

- The dissatisfaction with the e-banking services does depend on the lack of confidence in the electronic banking system and on the lack of respondents' knowledge on how to use a computer and/or Internet.

\section{Conclusion}

In the era of information technology e-banking is being more actualized from the aspect of improving of banking services implementation in order to increase banks' competitiveness. The level of e-banking services implementation differs in different countries. It depends on the level of social, economic and cultural development in the countries. Namely, in the developed economies, the e-banking implementation is on a very higher level compared to developing countries and underdeveloped countries. These differences underlie the different influences of the factors that are key to the modernization of banking services.

This research study seeks to determine the factors that affect the customer's satisfaction with e - banking services in the Republic of Macedonia. For this purpose, a conceptual model was developed, which included several factors such as: awareness, age, level of education, complexity, computer and internet knowledge and skills. These factors have a different level of impact on customer adoption and satisfaction from the e-banking services in Macedonian banking sector.

Testing of research hypothesis aimed to answer the question related to factors that affect the level of e-banking services application in the Republic of Macedonia showed that the age of clients, the level of education and complexity of e-banking services usage have influence towards the level of adaptation by the clients. More specifically, elderly clients use e-banking services less compared to younger population.

The level of e-banking services usage is significantly influenced by the higher level of education of clients compared to those with less education. In this context, clients who have computer knowledge and skills use these services more compared to those who fail to have this knowledge. 
With testing the hypothesis that refer to the level of satisfaction of clients with electronic bank services, it can be concluded that it does not depend on the quality, trust, safety and employee behaviour, but it depends on these services offer diversity as well as from the fast and simple completion of transactions. These results show that offer diversity and fast performance of e-banking services depend on the level of satisfaction of bank's clients, but not on their quality.

Advancing current technology in bank working has positive effect both for the banks and their clients. Namely, it means cost decrease and reducing time for completing transactions both for the banks and their clients. Due to these, banks should focus on undertaking suitable activities for greater informing of clients on advantages on using e-banking services, on increasing service variety as well as for the benefits that clients receive.

Because of the high level of competitiveness in bank sector, banks should continuously increase and improve its portfolio with new products and services, to advance the existing ones in order to retain and extend current users data. In order to accomplish this aim, it is essential that banks use segmented marketing strategies via direct communication with current and potential clients. In order to retain and increase its competitiveness advantage in variable business environment, it is necessary that the banks to be innovative, creative and identify their clients' needs on time. Having this access only, they will succeed in being recognizable compared to their competition and offer more quality product and services that would be in accordance with variable needs and requests from clients.

\section{References}

1. Alam, S. S., Musa, R., Hasan, F. (2009). Corporate Customer' Adoption of Internet Banking: Case of Klang Valley Business Firm in Malaysia. International Journal of Business and Management, Vol. 4, No.4, pp. 13-21.

2. Al-Smadi, M. (2012). Factors Affecting the Adoption of Electronic Banking: An Analyses of the perspectives of Bank's customers. International Journal of Business and Social Science, Vol.3, No.17, pp. 294-309.

3. Bucevska, V. (2012). An Empirical Analysis of Factors Affecting the Adoption of Electronic Banking in Macedonia: A logit Model. CD Proceedings of the International Conference Advances in Business-Related Scientific Research (ABSRC) Venice 2012, Venice, Italy, March 28 -30.

4. Chovanova, A. (2006). Forms of Electronic Banking. BIATEC, Vol. 14, pp. 22-25.

5. Delafrooz, N., Taleghani, M., Karami, R., Moradi, A. (2013). Factors Affecting the Adopiton of Internet Banking. International Journal of Business and Behavioral Science, Vol. 3, No. 2, pp. 82-100.

6. Dickinson, B. (2014). Customer loyalty: a multi-attribute approach. Research in Business and Economics Journal, Vol. 9, pp.1-17.

7. Drigă, I., Isac, C. (2014). E-banking services- Features, Challenges and Benefits. Annals of the University of Petrosani, Economics, Vol. 14, No. 1, pp. 49-58.

8. Fullenkamp, C., Nsouli, S. (2004). Six-Puzzles in Electronic Money and Banking. IMF Working Paper 04/19, pp. 1-30.

9. Gronroos, C. (1984). A service quaility model and its marketing implications. European Journal of Marketing, Vol. 18, pp. 35-44.

10. Hadžić, M. (2015). Banking. University Singidunum, Belgrade.

11. Islam, S., Ali, B. (2011). Measuring Service Quality of Banks: An Empirical Study. Research Journal of Finance and Accounting, Vol. 2, No. 4, pp. 74-85.

12. Karim, R., Chowdhury, T. (2014). Customer satisfaction on service quality in private commercial banking sector in Bangladesh. British Journal of Marketing Studies, Vol. 2, No. 2, pp. 1-11. 
13. Kovačević, M. S., Đurović, M. S. (2014). Electronic banking. Law - theory and practice, No. 01-03/2014, pp. 29-39.

14. Kumbhar, V. (2011). Factors affecting the customer satisfaction in E-Banking: some evidence form Indian banks. Management research and practice, Vol. 3, No. 4, pp. 1-14.

15. Lichtenstein, S., Williamson, K. (2006). Consumer Adoption of Internet Banking, Journal of Electronic Commerce Research, Vol. 7, No. 2, pp. 50-66.

16. Mia, A., Rahman, M., Debnath, N. (2007). Consumer Behavior of Online Banking in Bangladesh. Journal of Business Studies, Vol. 28, No. 2, pp. 151-181.

17. Montazemi, A., Saremi, H. (2013). Factors affecting the adoption of Internet banking. The European Financial Review, December 2013 - January 2014, pp. 18-20.

18. Muslime, A., Ramadhan, M. (2011). Internet banking, consumer adoption and customer satisfaction. African Journal of Marketing Management, Vol. 3, No. 10, pp. 261-269.

19. Parasuraman, A., Zeithaml, V., Berry, L. (1985). A conceptual model of service quality and its implications for future research. The Journal Marketing, Vol. 49, No. 4, pp. 41-50.

20. Petrovski, I. (2012). Interview with Caparovska Milica - Manager of the Sector for product management. Capital Magazine, No. 675. pp. 44-45.

21. Poder, B. (2005). Factors influencing the adoption and usage of Internet banking: A New Zealand perspective. Master Thesis, Auckland University of Technology.

22. Poposka, K. (2008). Commercial Banking - success and profitability. SI Institute of Economics, Skopje.

23. Radojević, P., Marjanović, D. (2011). Quality of Banking Services: Perception, gaps, dimension and research techniques for quality promotion. Banking, Vol. 7-8, pp. 34-59.

24. Rončević, A. (2006). New services of banking sector: The development of self-service banking in Croatia. Economic Review, Vol. 57, No. 11, pp. 753-777.

25. Srivastava, R. (2007). Customer's perception on usage of internet banking. Innovative Marketing, Vol. 3, No. 4, pp. 67-73.

26. Suki, N. (2010). An Empirical Study of Factors Affecting the Internet Banking Adoption among Malaysian Consumers'. Journal of Internet Banking and Commerce, Vol. 15, No. 2, pp. 1-11.

27. Zagorac, B. (2014). Innovative processes in the banking business. Master thesis, University Singidunum, Belgrade.

\section{About the authors}

Meri Boshkoska is an Associate Professor at the Faculty of Economics in Prilep, "St. Kliment Ohridski" University in Bitola. In 2009, she received her PhD in Economics at the Institute of Economics in Skopje, the Ss. Cyril and Methodius University in Skopje in the field of international finance. Her scientific research interest is focused on the following areas: international finance, financial management, international business and financial markets and institutions. The author can be contacted at: meribb@yahoo.com.

Kosta Sotiroski is a Full Time Professor at the Faculty of Economics in Prilep, "St.Kliment Ohridski" University in Bitola. He earned his PhD at the Faculty of Economics in Prilep following his dissertation entitled "Modelling optimal organization of the production process". His scientific research interest is focused on the following areas: business statistics, and business informatics. The author can be contacted at: kostasotiroski@gmail.com. 